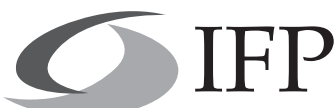

international federation for psychotherapy

\section{Conference of the International Federation of Psychotherapy: The Universal and the Cultural in Psychotherapy}

\author{
April 20-22, 2017, Marrakesh, Morocco
}

The International Federation for Psychotherapy (IFP) proposes the International Conference in Marrakesh, Morocco, on April 20-22, 2017. The conference aims at highlighting the role of the universal and the cultural in psychotherapy.

Delegates will have an enriching and rewarding experience attending keynote presentations and plenary lectures, participating in debates and scientific symposia on selected topics, and presenting oral communications.

We are very committed to ensure that the Marrakesh Congress will contribute to an improvement in the field of psychotherapy. We also hope that you will enjoy the reports on a broad spectrum of scientific and clinical approaches and the communication with old and new friends in an energetic city.

Welcome to the beautiful city of Marrakesh and to the 2017 Conference of the IFP! Paul Emmelkamp, IFP President

Driss Moussaoui, Congress President

For more details, please visit our web page www.cifp2017.com. 